IRSH 54 (2009), pp. 39-65 doi:I0.I0I7/S0020859009000029

(C) 2009 Internationaal Instituut voor Sociale Geschiedenis

\title{
Governing Aliens in Times of Upheaval: Immigration Control and Modern State Practice in Early Twentieth-Century Britain, Compared with Prussia
}

\author{
Christiane REINECKE \\ Sonderforschungsbereich 640, Humboldt-Universität Berlin \\ E-mail: reinecch@staff.nu-berlin.de
}

SUMmARY: In the history of immigration control, the period from the I 880 s to the I920s saw an international dynamic of growing restrictions. World War I in particular has been regarded as watershed marking the end of laissez-faire migration policy. But whether I9I4 can be seen as a crucial turning point depends on the country under consideration, as well as on the chosen analytical approach. Analysing Britain's politics of immigration control before and after the war and comparing it with its Prussian equivalent, this article discusses the shifts and continuities in the concrete administration of migration. Focusing on the changing practice of expelling foreigners, it suggests a chronology of control that does not entirely correspond with the overall political changes. By i9i 8, the British bureaucracy possessed elaborate means to monitor aliens, and the state increasingly impacted on the migrants' lives. In contrast, Prussia was maintaining a tightly regulated regime already, which its authorities had established well before igi4.

"The wild spirit of fury engendered by the war, and the selfish eagerness to make profit and secure power [...], have found their natural outcome in the Anti-Alien Bill." I In a letter to the editor, a reader of the Jewish Chronicle criticized the British postwar legislation on immigration in I919. For many of his contemporaries, the strict British migration regime of the early ig20s appeared to be a by-product of World War I that was closely linked to a time of upheaval and "national emergency". And

I. C.E. Maurice, "The Anti Alien Policy”, The Jewish Chronicle [hereafter, JC], 22 August 1919. 2. Several readers and editors joined in this protest. See, for example, N.S. Burstein, "Letter to the Editor", JC, 20 June 1919; "The Government and Aliens", JC, 28 March 1919; "The Government and Aliens”, JC, 24 October 1919. For the Chronicle's earlier stance on the eastern 
indeed in the British case, even though control procedures had already been implemented in the pre-war period, the war caused a distinct change in alien controls. While I905 had been a crucial turning point in British immigration policy, when the newly passed Aliens Act allowed the barring of undesirable aliens from entering the country, the war functioned as a major impetus to further restrictions. During the war, the British government extended its powers to control migrants both at the borders and within the country.

The shifts and continuities in immigration control were not only of interest at the time - they are also a recurring topic of historical discussions today. Historians' quest to determine the chronology of these developments is more than a mere technicality; it offers an important insight into the working of specific migration regimes as well as into the emergence of modern state practices in general. In the history of migration control, I9I4 has frequently been seen as a decisive watershed marking the end of laissez-faire migration policy and the advent of a "restrictive international migration regime". ${ }^{3}$ But while certain forms of control (like the ubiquitous demand to hold a passport when crossing international borders) appear to be linked to World War I, the policing of aliens had a longer tradition. ${ }^{4}$

By the late nineteenth century European bureaucratic actors often possessed the means to monitor and evict "undesirable" aliens. Prussia, for example, was already maintaining a tightly regulated regime, which its authorities had established during the r 880 os. And despite its liberal tradition, Britain enacted a law that allowed the control of immigration

Jewish immigration, see Dieter Schonebohm, Ostjuden in London. Der Jewish Chronicle und die Arbeiterbewegung der jüdischen Immigranten im Londoner East End, I88I-I900 (Frankfurt [etc.], 1987).

3. Aristide R. Zolberg, "Global Movements, Global Walls: Responses to Migration i 88 5-1925”, in Wang Gungwu (ed.), Global History and Migrations (Boulder, CO [etc.], 1997), pp. 279-307. According to Clifford Rosenberg, it was the Great War and the striving for total control in its aftermath that gave rise to an expanding police apparatus; Clifford Rosenberg, Policing Paris: The Origins of Modern Immigration Control between the Wars (Ithaca, NY [etc.], 2006). For the contemporary perspective see Imre Ferenczi, Kontinentale Wanderungen und die Annäherung der Völker. Ein geschichtlicher Überblick (Jena, I930); Alexander and Eugen Kulischer, Kriegs- und Wanderzüge. Weltgeschichte als Völkerbewegung (Berlin [etc.], 1932).

4. John Torpey, The Invention of the Passport: Surveillance, Citizenship and the State (Cambridge, 2000); Leo Lucassen, “A Many-Headed Monster: The Evolution of the Passport System in the Netherlands and Germany in the Long Nineteenth Century", in Jane Caplan et al. (eds), Documenting Individual Identity: The Development of State Practices in the Modern World (Princeton, NJ [etc.], 200I), pp. 235-255. According to Lucassen, early restrictive measures were closely linked to the concern with itinerant foreigners in the context of poor relief; Leo Lucassen, "Eternal Vagrants? State Formation, Migration, and Travelling Groups in Western Europe, I350-1914", in Jan Lucassen et al. (eds), Migration, Migration History, History: Old Paradigms and New Perspectives (Berne [etc.], 1997), pp. $225-25$ I. 
in 1905 . Broadly speaking, the whole period from the 1880 s to the $1920 \mathrm{~s}$ saw an international dynamic of growing restrictions on immigration. ${ }^{5}$ In what respect, and to what extent, I9I4 marked an important turning point in this historical context depends on the country under consideration, as well as on the chosen analytical approach.

So far, migration historians have identified a number of factors leading to a restrictive turn in immigration politics. Leo Lucassen has attributed this development to the labour movement and its quest to protect the national labour market. ${ }^{6}$ Moreover, increased interventionism has been said to derive from an emerging welfare state wishing to limit the access to its new provisions. ${ }^{7}$ Long-term processes like the nationalization of politics, ${ }^{8}$ as well as the emergence of an ethnically exclusive nationalism have been seen as major factors. ${ }^{9}$ And, stressing the extent to which the various national policies were connected, Aristide Zolberg has described the growing network of barriers as an "upward spiral of restriction". ${ }^{10}$

But whereas the nation state repeatedly figures as the central arena in which immigration control took place, the changing structures of modern state power, as well as the imperial dimension, have so far only partly been taken into account. Yet it seems worthwhile to analyse immigration control as an element of the rationalizing processes implemented by modern bureaucracies in order to render a society "legible", as described by James C. Scott. ${ }^{\text {II }}$ The emergence of the modern state served as a crucial background for restrictive migration regimes in the late nineteenth and early twentieth centuries. Striving to strengthen the bonds between their

5. On the history of migration control, see Andreas Fahrmeir et al. (eds), Migration Control in the North Atlantic World: The Evolution of State Practices in Europe and the United States from the French Revolution to the Inter-War Period (New York [etc.], 2003); Jochen Oltmer (ed.), Migration steuern und verwalten. Deutschland vom späten 19. Jabrbundert bis zur Gegenwart (Göttingen, 2003); Anita Böcker et al. (eds), Regulation of Migration: International Experiences (Amsterdam, 1998); Lucassen, Migration, Migration History.

6. Leo Lucassen, "The Great War and the Origins of Migration Control in Western Europe and the United States (I880-I920)", in Böcker, Regulation of Migration, pp. 45-72.

7. Michael Bommes and Jost Halfmann, "Einführung. Migration, Nationalstaat, Wohlfahrtsstaat", in idem (eds), Migrationen in nationalen Woblfabrtsstaaten. Theoretische und vergleichende Untersuchungen (Osnabrück, 1998), pp. 9-45.

8. Gérard Noiriel, Die Tyrannei des Nationalen. Sozialgeschichte des Asylrechts in Europa (Lüneburg, 1994).

9. See the debates on the possible impact of an ethnically exclusive nationalism on German citizenship law in Rogers Brubaker, Citizenship and Nationbood in France and Germany (London, 1992); Dieter Gosewinkel, Einbürgern und Ausschließen: die Nationalisierung der Staatsangehörigkeit vom Deutschen Bund bis zur Bundesrepublik Deutschland (Göttingen, 200I).

Io. Aristide R. Zolberg, “The Great Wall Against China: Responses to the First Immigration Crisis, I885-1925”, in Lucassen, Migration, Migration History, pp. 291-315, 292.

I I. James C. Scott, Seeing Like a State: How Certain Schemes to Improve the Human Condition Have Failed (New Haven, CT [etc.], 1998), p. 2. 
citizens and the state by defining the actual benefits of belonging, nation states also defined who was to be left out - excluded in the very spatial sense of not being admitted to the country or, less literally, in being denied citizenship.

Immigration control did not just consist of restrictive political goals. In order to consider the efficiency of a restrictive policy, ${ }^{\mathrm{I}}$ it is equally important to analyse the administrative practice and to investigate the bureaucratic infrastructure that authorities could use in order to manage immigration. Which factors caused the different states to intervene more strongly? How did they administer immigration? What did their restrictions imply for the migrants concerned? And to what extent did World War I engender changes in this context?

The following analysis investigates the British migration regime with regard to the state's expanding infrastructural powers in the years before and after the Great War. It focuses on the way in which migration was administered and explores the political and social dimensions of British immigration policy: (I) with regard to the political framework as it was debated internally by the officials and as it was formulated in laws, decrees, and orders in council; (2) with regard to the concrete practice of evicting alien immigrants, as it was documented in police records and reviewed by charities; and (3) in comparison with the ways in which Prussia administered immigration before and after World War I.

Within Europe, the German states, and Prussia in particular, were foremost in regulating the movement of foreign migrants at the borders and within the country. In the federative German Reich, the various Länder possessed far-reaching powers regarding the admittance, naturalization, or expulsion of immigrants. Prussia, as the largest and most influential of the German states, was comparatively independent in its policy regarding foreigners. It differed significantly from Britain in its administrative tradition: While British policy was guided by liberal values, Prussia was a more authoritarian and interventionist state. Whereas in late nineteenth-century Prussia the restrictions on work and residence for Polish immigrants added up to a well-regulated migration regime, British immigration policy was still one of the most liberal in Europe at the turn of the century. ${ }^{\mathrm{I} 3}$

The Prussian example illustrates most convincingly that restrictions on immigration started well before I9I4. The fact that by 1920 the British

I 2. Aristide R. Zolberg, "Matters of State: Theorizing Immigration Policy", in Charles Hirschman et al. (eds), The Handbook of International Migration: The American Experience (New York, 1999), pp. 7i-93.

I3. On German and British migration politics during the nineteenth century, see Andreas Fahrmeir, Citizens and Aliens: Foreigners and the Law in Britain and the German States, $1789-1870$ (New York [etc.], 2000). 
and the German migration regimes had come to resemble each other serves to demonstrate the restrictive dynamic in early twentieth-century migration control. While I9I4 might not have been the all-important watershed in migration policy, the early i920s can be seen as a terminus ante quem for the establishment of a restrictive international migration regime. By then, even liberal states like Britain had established an elaborate infrastructure in order to monitor and control immigration - an infrastructure that resembled that of countries with a more interventionist tradition, like Germany.

The first part of the article reconstructs the historical trajectory of British immigration politics. It concentrates on the changing legal framework and infrastructure of control from the mid-nineteenth century until the early I920s, in order to understand when and why the administrative powers of the state expanded. In what ways did the British authorities monitor and regulate immigration - and how and why did their powers increase? The second part of this article focuses on the practice of deporting alien immigrants from Britain and refers to the changing grounds and forms of exclusion before and after World War I. When forcing foreigners to leave, states obviously decisively influenced the personal situation of immigrants. Investigating the forced removal provides insight into changes in the micro-mechanisms of state regulation. ${ }^{\mathrm{I}}$ It allows a focused examination of the different actors involved, how they exerted their powers, and how this affected the individual migrants concerned. Finally, at the end of the article, the British "regime of restricted movement" is is contrasted with the Prussian one in order to discuss I9I4 as a shift within an international context. ${ }^{16}$

\section{IMMIGRATION CONTROL AND ADMINISTRATIVE POWER IN BRITAIN}

When formulating their new legislation on alien immigration in early twentieth-century Britain, law-makers could fall back upon the earlier British policy of the late eighteenth century. Similar to later regulations, these early restrictions were linked to a time of upheaval and political fear. Responding to the influx of French political refugees from revolutionary France, and due to the prevalent fear of Jacobinism, the British government

I4. On the "micro-mechanical" analysis of power structures, see Michel Foucault, Analytik der Macht (Frankfurt, 2005), pp. I I3-I I 8.

I s. M.B. Salter, Rights of Passage: The Passport in International Relations (London, 2003), p. 33 .

I6. As in Germany the immigration policy of the different Länder varied, the following analysis concentrates on Prussia, which at the time received the highest numbers of immigrants and refugees within the German Reich. 
in 1793 introduced a strict law regulating immigration. ${ }^{17}$ Immigrants entering Britain had to possess a passport and were only permitted to land at certain approved ports. In addition, the executive had been given the power to expel foreigners if they expressed unwelcome political opinions or were considered undesirable in any other way. With the fear of Jacobinism subsiding, the Act was repealed after the Napoleonic Wars, and - apart from a brief interval in I 848 - the old legal provisions were not renewed.

After the mid-nineteenth century, immigrants did not even have to produce a passport or undergo inspection when arriving in British ports. So by 1889 , when a parliamentary committee reported on immigration into Britain, its members claimed that they did not possess any concrete data on the number of immigrants entering or leaving the country. ${ }^{{ }^{8}}$ By that time, older provisions, which obliged shipmasters to make lists of the aliens travelling on their vessels, had fallen into disuse, and it was only after the committee's complaints that customs officers were requested again to register the number of incoming migrants. They boarded the arriving ships, received the lists, and called out the names of the individual aliens, asking them where they came from and where they intended to go. ${ }^{19}$ However, customs officers could not hinder aliens from entering the country. Hence, for most of the nineteenth century, the British executive neither possessed any powers to remove alien citizens from the country - with the exception of Irish migrants, who could be deported - nor could immigrants be refused entry or be given specific conditions as to their residence. ${ }^{20}$

Even though, as will be shown later, some charities exerted a form of voluntary immigration control by repatriating destitute migrants, until the early twentieth century the British state abstained from interfering with the mobility of aliens coming into Britain. In this respect, the Aliens

I7. J.R. Dinwiddy, "The Use of the Crown's Power of Deportation Under the Aliens Act, 1793-1826", in Bulletin of the Institute of Historical Research, 4I (1968), pp. 193-2 I I; T.W.E. Roche, The Key in the Lock: A History of Immigration Control in England from 1066 to the Present Day (London, 1969); Fahrmeir, Citizens and Aliens.

I 8. Parliamentary Papers [hereafter, P.P.] (Commons), Session i 889, X, Select Committee on Emigration and Immigration (Foreigners); together with the Proceedings of the Committee, Minutes of Evidence and Appendix, August I 889. A contemporary comment on alien statistics see in W.H. Wilkins, The Alien Invasion (London, I892), p. I 52.

19. This was not the case in all ports. In some merely the overall number of arrivals was noted, mostly without even entering their nationality. P.P. (Commons), Session 1903, IX, Report of the Royal Commission on Alien Immigration with Minutes of Evidence and Appendix (London, I903), p. 40.

20. Andreas Fahrmeir, "Grenzenloser Liberalismus. Die britische Einwanderungspolitik im I 9. Jahrhundert”, in Karin Schönwalder et al. (eds), Die britische Gesellschaft zwischen Offenheit und Abgrenzung: Einwanderung und Integration vom I8. bis zum 20. Jabrbundert (Berlin, 200I), pp. 57-71; Fahrmeir, Citizens and Aliens; David Feldman, "Was the Nineteenth Century a Golden Age for Immigrants? The Changing Articulation of National, Local and Voluntary Controls", in Fahrmeir, Migration Control, pp. I67-177. 
Act of 1905 marked a crucial turning point. Anti-alien sentiment had increased and gained popular support amongst the British public since the late nineteenth century. The contemporary debates on immigration focused almost exclusively on the Polish and Russian Jews who had been coming to Britain from 1880 onwards. ${ }^{21}$ In response to a xenophobic discourse that depicted alien immigrants as insanitary destitutes who overpopulated the metropolis and displaced native labour, British policy primarily aimed to exclude pauper aliens, who were considered a burden to the labour market or to Poor Law relief. ${ }^{22}$

So after 1905, arriving migrants were interrogated by immigration officers at the ports. They had to prove that they could support themselves as well as their "dependants", which usually meant their wives and children. If not, they were denied access to the country. Immigrants could also be refused permission to land on medical grounds. When they were judged to be either an actual threat to public health, or to be of a physical condition that hindered them from earning their own living, they were sent back. As the British authorities were mostly concerned with aliens unable to support themselves, only steerage passengers were subjected to investigations at the ports, whereas cabin passengers (who had paid more for their tickets) could enter freely. ${ }^{23}$

The Aliens Act of 1905 hence responded to the Poor Law concerns of local and state authorities, which were striving to reduce the number of potential public charges. ${ }^{24}$ Since, in contemporary discourse, immigration was frequently depicted as a "sanitary danger", the newly established controls were also considered to advance "public health". And underlying these explicit political goals of immigration control, the aim to keep out undesirable aliens answered anti-alien, and at times anti-Semitic, demands which particularly focused on the exclusion of eastern European Jews.

In general, the British pre-war endeavours to control immigration concentrated on the borders and the monitoring of ships in certain ports.

21. Arnold White, The Destitute Alien in Great Britain: A Series of Papers Dealing with the Subject of Foreign Pauper Immigration (London, I 892); The Earl of Dunraven, "The Invasion of Destitute Aliens", in The Nineteenth Century, 3 I (1892), pp. $985-1000$; W.H. Wilkins, The Alien Invasion (London, I892); Major Williams Evans-Gordon, The Alien Immigrant (London, I903).

22. On British late nineteenth-century immigration politics, see Bernard Gainer, The Alien Invasion: The Origins of the Aliens Act of 1905 (London, 1972); John Garrard, The English and Immigration: A Comparative Study of Jewish Influx, I880-1910 (London, 1971); Colin Holmes, John Bull's Island: Immigration and British Society, I87I-I97I (London, I988); David Feldman, Englishmen and Jews: Social Relations and Political Culture, I840-I9I4 (New Haven, CT [etc.], 1994); Schönwalder, Die britische Gesellschaft.

23. Only large ships carrying a certain number of passengers were scrutinized, whereas smaller ones were not policed.

24. See, for example, the summary of arguments against immigration in the Report of the Royal Commission on Alien Immigration: P.P. (Commons), Session 1903, IX, Aliens Immigration (Royal Commission), I, pp. 5 f., i 5 f. 
Since loopholes in the regulations allowed immigrants ample opportunity to circumvent scrutiny and to enter without being monitored, the controls implemented a "political selectivity" rather than aiming for zero immigration. ${ }^{25}$ Prior to 1914, immigrants who had been denied access even possessed the right to challenge this decision. They could present their case to an Immigration Board consisting of local citizens, who had the power to review and overturn their refused entry. ${ }^{26}$ The post-1905 restrictions not only resulted in the de facto exclusion of aspiring immigrants, but were likely to deter many who abstained from even making the passage. ${ }^{27}$ However, within the country, alien citizens neither had to register with the police, nor did they need residence permissions or labour permits. They could only be deported if a court recommended their eviction. But alien immigrants remained mostly unaffected by state authorities once they had succeeded in entering the country.

Undoubtedly, the passing of the Aliens Act in I905 allowed the British authorities to establish an infrastructure of migration control at the borders. And yet, not all officials thought these powers to be sufficient. Hence, the Inspector under the Aliens Act considered the Act to be "restricted in its operation". ${ }^{28}$ Referring to the same law, Sir Edward Troup, the UnderSecretary in the Home Office, commented that from the administrative point of view it was "one of the worst [Acts] ever passed". ${ }^{29}$ In his opinion, the regulations of 1905 "opened very wide doors for the admission of undesirables", whereas it took the outbreak of World War I to bring about a "more effective" law. ${ }^{3 \circ}$ With the beginning of the war, much stricter regulations as to the treatment of alien citizens were indeed introduced. Ministerial officials had already been preparing these new provisions internally since i9io. In view of an eventual war and the necessity of "imperial defence", the executives were aiming for extended powers, which they were finally granted with regard to a prevailing state of "national danger" in I $914 .{ }^{31}$

\footnotetext{
25. Sciortino has rightly emphasized the need to differentiate more clearly between these two political goals in immigration policy; Giuseppe Sciortino, "Toward a Political Sociology of Entry Policies: Conceptual Problems and Theoretical Proposals", Journal of Ethnic and Migration Studies, 26 (2000), pp. 21 3-228, 220.

26. M.J. Landa, The Alien Problem and its Remedies (London, I91 I), p. 200-229; N.W. Sibley and Alfred Elias, The Aliens Act and The Right of Asylum (London, I906), p. 54.

27. According to Zolberg, the measures served as an "effective deterrent", since immigration declined immediately; Zolberg, Global Movements, p. $30 \mathrm{I}$.

28. National Archives, Kew [hereafter, NA], $\mathrm{HO}_{45} / 10828 / 322712 / 25$, Memorandum as to "The Admission of Aliens to the United Kingdom".

29. Edward Troup, The Home Office (London [etc.], I925), p.I43.

30. Ibid., pp. I 43 f.

3 I. NA, CAB I7/90; NA, CAB 38/25/34. On the Standing Sub-Committee of the Committee of Imperial Defence on the Treatment of Aliens in Time of War, see also Panikos Panayi, The Enemy in our Midst: Germans in Britain during the First World War (New York [etc.], 1991), pp. $38 \mathrm{f}$.
} 
When it was introduced to parliament in August I9I4, the new alien legislation met the fervent support of a nationalist public adverse to "enemy aliens" either coming to or staying in the country. ${ }^{32}$ Hostility at the time focused particularly on German immigrants. ${ }^{33}$ When public opinion had turned against Prussia after its victory over France in I871, this hardly affected the German community in Britain. ${ }^{34}$ But while antiGerman feeling was only sporadic prior to the I 890s, Germanophobia became increasingly common, in particular with regard to Germany's imperial and naval expansionism. ${ }^{35}$ Since the late nineteenth century, newspapers and novels had successfully popularized a narrative that depicted all Germans as spies plotting against an unguarded British people and planning an invasion. ${ }^{36}$ Consequently, at the beginning of the war an agitated public demanded the monitoring, confining, and deportation of all "enemy aliens" living in Britain.

At the "expense of the common law and parliamentary responsibility", the post-I9I4 emergency powers of British officials curtailed the rights and freedoms of aliens who could be detained or removed without any legal proceedings. ${ }^{37}$ About 32,000 "enemy aliens" were interned and about 20,000 were repatriated. ${ }^{3}$ Immigrant officers could now board any vessel, and examine and detain every person arriving or leaving the country. All non-British citizens had to register with the police and were requested to possess an identity card that documented their registered status. In addition, aliens were restricted in their movements and were prohibited from entering certain areas. If classified as "enemy aliens", they were generally not permitted to travel more than five miles from their place of residence without a specific permit. ${ }^{39}$ And while the policy initially only targeted "enemy aliens", it increasingly concerned all alien citizens.

32. Parl. Debates (Commons), I914, LXV (56), pp. 1986-1990.

33. Panayi, The Enemy in our Midst; Stefan Manz, Migranten und Internierte. Deutsche in Glasgow, I864-1918 (Wiesbaden, 2003).

34. Panikos Panayi, German Immigrants in Britain during the I9th Century, I8IS-I9I4 (Oxford [etc.], 1995), p. 233.

35. Ibid., pp. 228-251.

36. Le Queux's Spies of the Kaiser was one of the most successful spy stories at the time; William Le Queux, Spies of the Kaiser: Plotting the Downfall of England, introduction by Nicholas Hiley (London [etc.], I 996 [1909]). On spy fear and its influence on the actual alien policy, see the introduction by Nicholas Hiley, in ibid., pp. vii-xxxii; Panayi, The Enemy in our Midst, pp. I 53-183; idem, German Immigrants in Britain, pp. 239-245.

37. Kay Saunders, “The Stranger in our Gates': Internment Policies in the United Kingdom and Australia during the Two World Wars, 1914-39", Immigrants and Minorities, 22 (2003), pp. 22-43, 38. With regard to both World Wars, Saunders points to the "unprecedented expansion of executive powers in liberal democratic societies"; ibid., p. 22.

38. J.C. Bird, Control of Enemy Alien Civilians in Great Britain, 1914-I9I8 (New York [etc.], I986), p. 8.

39. Arthur Page, War and Alien Enemies (London, 1915). 
In the context of the war, and as a result of a military rationale of ensuring "national security", the British authorities began to regulate the mobility of foreign citizens not only at the borders, but also within British territory. In this context, they installed an elaborate infrastructure in order to accumulate and process data on the foreign population living in the country. They now possessed a central register containing information on both friendly and enemy aliens. Due to the official demand for passports and identity cards displaying photographs, they also had an improved means of identifying foreign citizens at their disposal. And in addition, new officers were recruited in order to supplement the existing immigration officers. ${ }^{4}$ The authorities were installing structures that facilitated any further implementation of political decisions. Referring to a concept of Michael Mann, they can be said to have expanded the "infrastructural power" of the state in the process. ${ }^{4}$ The increased intervention in the field of immigration control after I9I4 thereby coincided with a general expansion of state activity, as the proclaimed time of "national emergency" allowed British authorities to intervene more strongly in various fields of social life..$^{42}$ As James E. Cronin commented with a view to the unprecedented degree of state expansion at the time, the limited state was "but a memory" by 1918.43

The logistics, which had been established in order to monitor aliens as potential spies and enemies during the war, were for the most part maintained during the following years. With the Aliens Restriction Act of I919 and the associated Aliens Order of 1920, immigration officers retained their extended powers over the admittance of immigrants. Moreover, the pre-war practice of establishing immigration boards was not taken up again. ${ }^{44}$ Passports and visas were obligatory. And responding to protectionist fears that foreign labour would increase unemployment, aliens were required to possess labour permits if they entered the country

40. Many were stationed in ports where previously incoming aliens had not been controlled at all; Roche, The Key in the Lock, p. 79.

4I. Michael Mann, "The Autonomous Power of the State: Its Origins, Mechanisms and Results", in Archive Européennes de Sociologie, 25 (1984), pp. I85-213; idem, The Sources of Social Power: II: The Rise of Classes and Nation-States, I760-19I4 (Cambridge, 1993).

42. For an early analysis of the impact that World War I had on the British state and the development of economic controls, see Samuel J. Hurwitz, State Intervention in Great Britain: A Study of Economic Control and Social Response, 1914-1919 (New York, 1949). While emphasizing that state expansion should not be analysed as a mere linear process, Cronin also underlines the significance of both World Wars for the expansion of state activity in Britain; James E. Cronin, War, State and Society in Twentieth-Century Britain (London [etc.], I99I), pp. $65-92$.

43. Ibid., p. 72 .

44. The new regulations were established in the form of an Order in Council that was originally passed for only one year, and that came to be renewed annually up to I97I. 
and intended to take up work. ${ }^{45}$ Even though the immediate threat to "national security", which had justified the earlier restrictions, had subsided, officials seemed reluctant to do without the extended powers and administrative tools at their disposal. The maintenance of the National Alien Register points to this logic of bureaucratic self-perpetuation and aggrandizement. Being considered essential for public safety, compulsory registration had been introduced both for British subjects and for nonBritish residents during the war. ${ }^{46}$ At first only "enemy aliens" had to comply with this rule, but in I9I 6 all aliens were required to register and hold an "identity book". After 1918, the rule that aliens had to register with local police was retained, even though it was abolished for British subjects. ${ }^{47}$

Commenting on the question of what was to be done with the data on alien citizens, a ministerial official who worked for the Aliens' Branch of the Home Office declared that the register was "a necessary part of the equipment $[\ldots]$ for the purpose of controlling aliens". The Home Office, he maintained, could not afford "to be deprived of the information which the Register does or can afford in regard to the numbers, nationality and location of aliens in this country". The register, he concluded, was capable of "giving good value for a moderate expenditure".$^{8}$ Whereas only some years before no such register existed, it was considered a crucial administrative tool by 1920. Even though its maintenance rather contradicted classic liberal ideas of a minimal state apparatus causing minimal costs, registration continued. Another "logistical tool" was the staff in charge of immigration control. The Immigration Service became an increasingly professional and specialized branch of the Home Office; its staff was further extended, and the ranks, titles, and responsibilities were defined more clearly. ${ }^{49}$

Of course, the considerable institutional autonomy of a bureaucracy arguing for its own maintenance and expansion was not the only factor influencing British immigration policy. Nevertheless, it was a crucial element supporting continued interventionism after the end of the war.

45. House of Commons, Accounts and Papers. Session 1928/1929, XVI, Memorandum by the Minister of Labour on "The Procedure Regulating the Entry of Foreigners for Employment in Great Britain”, pp. 513-5 18. British employers who desired to hire workers from abroad had to apply to the Ministry of Labour for a permit and they had to guarantee that no British labour would be displaced; NA, LAB 2/1187/4/EDAR68I2/1919; NA/LAB 2 Ii87/EDAR/2974/ I922.

46. Metropolitan Police (ed.), Aliens: Handbook of Regulations (London, 1918). On national registration as regards British subjects, see Jon Agar, "Modern Horrors: British Identity and Identity Cards", in Caplan, Documenting Individual Identity, pp. I०I-1 20, 10I-106.

47. Aliens Order 1920, Part 2, § 6-8.

48. NA, $\mathrm{HO}_{45} / \mathrm{I} 2258$, John Pedder, "Minutes on the Central Register of Aliens".

49. Roche, The Key in the Lock, pp. 96, 100. 
In view of the industrial unrest and racial outbursts of the early postwar years, to restrict immigration was also presented as a way to counteract social and political disturbances in the aftermath of the war. The exclusionary concerns of the early ig20s thereby followed demands to give British workers and demobilized soldiers preference in the national labour market. In addition, authorities aspired to exclude aliens deemed to be "Bolsheviks". 50 Moreover, ethnically exclusive and racialist elements began to influence the agenda of the British alien policy more explicitly. ${ }^{5 \mathrm{I}}$ Due to widespread anti-German sentiment, British media and political representatives were aligned in their demand for a strict stance on immigration policy. Apart from the unbroken hostility against German former "enemy aliens" older anti-alien or anti-Semitic sentiments focusing on the Russian Jewish community influenced the policy of the early postwar years. ${ }^{52} \mathrm{~A}$ third group that was subjected to discrimination were the so-called "coloured seamen". 53

As part of the ongoing process of constructing racial difference, the category "black" or "coloured" at the time referred to a broad and ethnically disparate group, including West Indian as well as African or Arab seamen. It primarily denoted a population belonging to "the colonized" in Britain's overseas empire. ${ }^{54}$ From the late nineteenth century, and particularly during the war, "black seamen" made up a significant part of the workforce in the British merchant fleet. But with unemployment on the rise, and racial hostility increasing during the early postwar years, both local and state officials came to regard these seamen as most unwelcome labourers. ${ }^{55}$ Despite the fact that many of the seafarers actually were British subjects or

50. Kadish claims that between I9I7 and I92 I anti-Bolshevism and an "older-strain of antialienism" mixed; Sharman Kadish, Bolsheviks and British Jews: The Anglo-Jewish Community, Britain and the Russian Revolution (London, 1992), pp. 44-54.

5I. Referring to British nationality law, Sven Oliver Müller has pointed to the increasing significance of biological criteria in British alien policy during the war; Sven Oliver Müller, "Recht und Rasse. Die Ethnisierung von Staatsangehörigkeit und Nationsvorstellungen in Großbritannien im Ersten Weltkrieg”, Geschichte und Gesellschaft, 30 (2004), pp. 379-403.

52. Holmes, John Bull's Island, pp. I I 2-I I4; Panayi, The Enemy in our Midst; David Cesarani, "An Alien Concept? The Continuity of Anti-Alienism in British Society before 1940", in idem et al. (eds), The Internment of Aliens in Twentieth Century Britain (London, I993), pp. 25-53; idem, "Anti-Alienism in England After the First World War", Immigrants and Minorities, 6 (1987), pp. 5-29.

53. Neil Evans, "Regulating the Reserve Army: Arabs, Blacks and the Local State in Cardiff, 1919-45", Immigrants and Minorities, 4 (1985), pp. 86-106. On the imperial context of the hostility against black people in postwar Britain, see idem, "Across the Universe: Racial Violence and the Post-War Crisis in Imperial Britain, I919-25”, Immigrants and Minorities, I 3 (1994), pp. 59-88.

54. Laura Tabili, "The Construction of Racial Difference in Twentieth Century Britain: The Special Restriction (Coloured Alien Seamen) Order, 1925”, Journal of British Studies, 33 (1994), pp. 54-98. 55. NA, $\mathrm{HO} 45 / 11897$. 
"British protected persons", the state administration began to subject them to restrictions, knowing very well that these workers usually did not possess passports or other proof confirming their place of birth and hence their British nationality.

The unclear or undocumented legal status of "black" seamen was thus turned against them, especially when in 1925 a registration scheme was introduced under the "Coloured Alien Seamen Order". ${ }^{56}$ It requested all "coloured seamen" (other than their non-coloured colleagues) to register with the police immediately upon arrival, if unable to prove they were British subjects. Moreover, they had to hold specific identity cards. As they were registered as aliens, it was possible to deport them at any time. Having been welcome workers during the war, the seamen became "undesirables" threatened with imminent removal in the early ig2os. In the context of a policy that aimed to reduce new entrants to the labour market, the British authorities thus used the alien regulations against black British subjects and implemented the racialized hierarchies of colonial rule at home. ${ }^{57}$

Whereas forms of immigration control had already been established in the pre-war period, the beginning of war nevertheless produced change. Before I9I4 officials were closely bound to legal provisions. With the help of the new "emergency powers" they could act more independently of parliamentary control. Their increased infrastructural, personal, and financial resources allowed them to install structures that facilitated the close surveillance and exclusion of alien subjects. They thus gained extensive powers to monitor, exclude, intern, or deport immigrants not only at the borders, but also within the country. The modern bureaucratic endeavour to register and identify certain groups not only served to increase knowledge of their numbers and whereabouts, but also became a means of their exclusion.

Several long-term developments influenced the overall regulative turn during the early twentieth century. The fear of social tensions among the domestic working class overlapped with social-political concerns to reduce the number of beneficiaries to Poor Law and welfare services. Anti-alienist sentiments combined with an exclusivist national discourse that gained momentum in the aftermath of the Boer War and in view of Anglo-German rivalry. Also, when a militarized and nationalized "friendor-foe" perspective became pervasive in the pre-war period, immigrants

56. Thomas Lane, "The Political Imperatives of Bureaucracy and Empire: The Case of the Coloured Alien Seamen Order, I925”, Immigrants and Minorities, I3 (1994), pp. I04-I29; Tabili, "The Construction of Racial Difference".

57. For an earlier appeal to keep out immigrants for the sake of the British Empire, see for example H. Hamilton Fyfe, "The Alien and the Empire", The Nineteenth Century and After, 54 (1903), pp. 4I4-419. "Any federation of the British race", Fyfe claimed, was "out of the question if we allow our population in these islands to be contaminated and dragged down by the presence of an alien element"; ibid., p. 418. 
increasingly came to be perceived as a security risk. At the same time, the labour market did not counteract restrictions. Because of the limited need for labour before the war and in view of the unemployment of the I920s, the demand for migrant workers was not high enough to stand against restrictions. As in other political fields, the outbreak of war catalysed interventionist tendencies and triggered long-term changes. In view of a proclaimed state of "national emergency", executive powers in the field of immigration control expanded.

However, when examining how these changes affected the way in which individual immigrants were treated, the concrete policy and the diverse agencies involved should be taken into account. In this context, the following part concentrates on one particular governmental instrument: the practice of deporting alien subjects before and after World War I.

\section{THE CHANGING PRACTICE OF DEPORTING ALIEN IMMIGRANTS}

The forced removal of aliens is just one element of immigration control. Others, like entry controls with the help of visa and border controls, registration with the police, or the introduction of work permits, have been mentioned in the preceding chapter. Deportations were commonly employed in order to exclude migrants considered to be unwelcome for various reasons; for example as criminals or paupers. As a consequence, an analysis of the concrete practice of expulsion enables an understanding of the micro-mechanisms of inclusion and exclusion which characterized British policy at the time. Moreover, the practice of deporting aliens indicates how far the state was prepared to intrude on migrants' lives once they had entered the country.

Citizenship implied a protection against deportation from a state's territory. To be a citizen usually meant to be entitled to live in a state and to be protected from deportation. ${ }^{58}$ For foreigners the case was different: Within the limits that national law, administrative practice and international custom defined, foreigners could be forbidden to stay in or move through a state's territory. They could be expelled. National bureaucracies of the early twentieth century differed considerably in their legal provisions and administrative practice of deporting foreigners. ${ }^{59}$ Whilst evictions had

58. On the relation between deportation policies and citizenship in the German case, see Andreas Fahrmeir, "Nineteenth-Century German Citizenships: A Reconsideration", The Historical Journal, 40 (1997), pp. 72 I-752.

59. For a more general analysis of late nineteenth- and early twentieth-century expulsion policy, drawing on the Belgian, Dutch, French, and Prussian example, see Frank Caestecker, "The Transformation of Nineteenth-Century West European Expulsion Policy, I880-1914", in Fahrmeir, Migration Control, pp. I20-137. 
been a crucial element of Prussian policy since the 1880 os and remained so after World War I, they were more cautiously employed in pre-war Britain. ${ }^{60}$ In view of Britain's geographical position as an island, which was less easily accessible to travellers than continental countries, British immigration control mainly relied on the monitoring of immigrants at the borders. Nevertheless, after 1905 it became possible for authorities to order the eviction of "undesirable" aliens. In this context, the changes in the practice of deporting alien immigrants indicate a changing role of the British state in the field of immigration control before and after World War I.

At the time when a more restrictive immigration policy was introduced, the traditional Poor Law administration which had been established under the Poor Law Act of I 834 slowly gave way to structures that are now commonly regarded as foundations of the modern British welfare state. With the introduction of old-age pensions in 1908 and the National Insurance Act of I9II, the British state started to introduce centrally financed and administered welfare services in order to reduce the social and economic insecurities of individuals and families. Other than the old Poor Law provisions which morally stigmatized the recipients, these services slowly developed into a common "social right". In this context, questions of eligibility and the distinction between being or not being a British subject became increasingly important.

The London County Council, for example, began to exclude aliens explicitly from social services. It thus decided in I9I 8 that only children of British nationality were eligible for council scholarships. In 1920, the council determined that (except in the case of foreign-language teachers), only natural-born British subjects were to be employed in council posts. ${ }^{61}$ But irrespective of the emergence of centrally financed and administered welfare services, the concern with immigration as a factor enhancing social tensions had already been central to late nineteenth-century debates. This was especially the case in districts like the London East End, where large numbers of aliens resided. The forced or assisted removal of destitute and other "undesirable" aliens was a frequent matter of concern.

Whereas in the late eighteenth century the British government had been granted the right to expel foreigners in response to the influx from revolutionary France, it relinquished this power in the I820s. For most of the following century, the British executive did not possess the right to expel aliens. The Aliens Act of I 848 allowed the eviction of any person

60. On the mass expulsions of Russian-Polish and Jewish migrants in Prussia, see Helmut Neubach, Die Ausweisungen von Polen und Juden aus Preussen 1885/86. Ein Beitrag zu Bismarcks Polenpolitik und zur Geschichte des deutsch-polnischen Verhältnisses (Wiesbaden, 1967). 61. Geoffrey Alderman, London Jewry and London Politics, I889-1986 (London [etc.], I989), pp. $66 f$. 
considered a threat to the realm, but the provision was hardly used and lapsed in $1850 .{ }^{62}$ And yet, even before the Aliens Act of 1905 allowed officials to order evictions, a high number of "undesirable" immigrants left the country through other channels. British charities assisted numerous aliens in leaving the country when they were becoming a burden on poor relief. So when in 1889 and 1903 two commissions investigated the situation of alien immigrants in Britain, the representatives of several charities reported on their relief work and highlighted their practice of supporting destitute immigrants in leaving the country.

The Jewish Board of Guardians as well as other organizations either repatriated "undesirables" to their countries of origin, or helped them to emigrate to the United States, Australia, or Canada. A high percentage of the aliens in distress who sought assistance were sent back to their home countries. Of the 908 persons helped by the French Societé Française de Bienfaisance in I 888, about one-third was sent back to Calais or Paris. ${ }^{63}$ Assisting the Russian and Polish Jews, who formed the largest immigrant community, the Jewish Board of Guardians and the Russo-Jewish Committee between I895 and 1902 helped foreigners emigrate and repatriate in $10, \mathrm{I}_{4}$ cases (a family being "a case"). ${ }^{64}$ To support pauper aliens in emigrating or in repatriating thereby mimicked emigration schemes under the existent Poor Law, as Poor Law authorities until the early twentieth century assisted numerous British paupers in emigrating to the colonies.

By organizing the removal of "undesirable aliens", charities like the Board of Guardians exerted a form of voluntary migration control. Reporting to the Royal Commission in 1903, the President of the Board, L.L. Cohen, readily conceded that he considered a certain number of the immigrants to be "not suitable":

As soon as this undesirable, or failure, as I call him, presents himself to us, we deal with him by repatriating him [...]. We point out to him that he has not succeeded and is not likely to succeed here, and he acquiesces in the view that he had better return home. ${ }^{65}$

62. Panayi, German Immigrants in Britain, pp. 228f.; Dinwiddy, “The Use of the Crown's Power of Deportation".

63. P.P. (Commons), Session I889, X, Select Committee on Emigration and Immigration (Foreigners), Minutes of Evidence and Appendix, August i889, pp. 9 f.

64. P.P. (Commons), Session 1903, IX, Aliens Immigration (Royal Commission); III, p. 94, Table 8I, "Cases Dispersed by the Jewish Board of Guardians and Russo-Jewish Conjoint Committee". On the repatriations by the two organizations, see Severin A. Hochberg, "The Repatriation of Eastern European Jews from Great Britain, I88 I-1914", Jewish Social Studies, 50 (1988), pp. 49-62; David Feldman, Englishmen and Jerws, pp. 303f. According to Feldman the Jewish Board repatriated over 50,000 aliens between I 880 and I9I4; ibid., p. I 56.

65. P.P. (Commons), Session 1903, IX, Aliens Immigration (Royal Commission); II, "Examination of L.L. Cohen", pp. 527-545, 542. 
With regard to anti-alien feeling, the Jewish community was anxious to prevent immigrants from causing any public annoyance, which could have exposed the whole community to hostilities. The example of a group of 650 Romanian Jews seeking refuge in Britain in the summer of 1900 illustrates this point. When reaching London, most of the arrivals did not have any relatives in the city and proceeded to the Jews' Temporary Shelter, an institution offering food and temporary accommodation to migrants. Intending to avert any public attention, the Shelter first opted to repatriate the new guests. When meeting opposition, it sent them on to various parts of the world: 316 were sent to Canada, IO2 to the United States, and 8 to Paris, so that altogether 426 out of 650 left the United Kingdom within 5 weeks of their arrival. ${ }^{66}$ In addition, more than I,400 newly arrived Romanians were repatriated later. ${ }^{67}$ The authorities regarded this measure to be in the immigrants' best interest as well as their own. Had it not been for the Shelter, a member of the Jewish Board declared later, these "poor wanderers would have been parading the streets of London, homeless and hopeless, with dangerous results to themselves and the whole Jewish community". ${ }^{68}$

Publicly, the members of the Jewish Board of Guardians presented their work as a form of voluntary self-regulation, so that immigration did not "become excessive". ${ }^{69}$ But in spite of this intention to counteract public criticism, critics still used the existing repatriation schemes in order to justify their restrictive agendas. The attitude of the well-known antialienist, Major Evans-Gordon, may be taken as a characteristic example of that. Addressing the Board's representative L.L. Cohen before the Royal Commission, he asked: "If it is desirable that this immigration should be restricted, why should you object to the state attempting to do what you consider is advisable to attempt to do yourself?"70 In the eyes of Evans-Gordon and other restrictionists, it was the state that should take over and regulate immigration.

By aiming to reduce the number of "undesirable" aliens in the country, members of civil society in late nineteenth-century Britain assumed functions that, during the following years, were indeed increasingly taken on by the state. As a consequence of the legislation of 1905 and I9I4, the state authorities gained the power to hinder the entrance of "undesirable" aliens and to enforce their removal. Simultaneously, the activity of the charities slowly came to a halt. After 1905, the number of aliens repatriated by the

66. London Metropolitan Archives [hereafter, LMA], LMA/4184/02/05/001/001, pp. 35f.

67. Hochberg, "The Repatriation of Eastern European Jews", p. 55.

68. LMA/4I84/02/05/001/001, p. 35.

69. P.P. (Commons), Session I903, IX, Aliens Immigration (Royal Commission); II, "Minutes of Evidence, Examination of L. L. Cohen", p. 537.

70. Ibid., p. 537. 
Board of Guardians began to decline and by r9 10 had decreased significantly. ${ }^{71}$ During the war, the repatriations by the Board and the Russo-Jewish Committee came to a halt and after i9i 8 , they were no longer undertaken. ${ }^{72}$ By then, the voluntary migration control that the charities exerted had lost its significance. The war, it seems, had accelerated a process of centralization. During the war, immigration control became the exclusive responsibility of the state.

Not only the actors involved in the regulation and control of immigration changed. British policy with regard to aliens also increasingly impacted on immigrants' everyday lives and rights - both at the borders and within the country. This is illustrated by the changing ways of evicting aliens. Upon comparing the official deportation policy before and after World War I, some significant differences become apparent: (I) The Secretary of State now possessed the power to order deportations without being dependent on the Courts; (2) the measure itself was implemented more stringently, as aliens had to endure prolonged internment before leaving the country, being then directly brought to their ships by police officers rather than leaving on their own account within a given period; and (3) the grounds on which aliens were expelled differed.

Under the Aliens Act of 1905, the Secretary of State could only order the eviction of "undesirable aliens" (like criminals, recipients of poor relief, or the mentally ill), if a Court recommended such an eviction. But - though repeatedly criticized by ministerial officials - magistrates were rather hesitant in recommending convicted aliens to be deported, and the Secretary of State did not always comply with the recommendations that were made. ${ }^{73}$ The power to evict aliens was thus handled rather cautiously. Most of the eviction orders at the time concerned "criminal aliens": after having convicted them of offences, the courts could recommend alien convicts for deportation. ${ }^{74}$ But in addition,

7I. For the actual numbers, see University of Southampton Library, I/I2/7-I/I2/9, Jewish Board of Guardians [hereafter, JBG], Annual Reports (1902-192I). In I910, the Board reported that in only 325 cases new arrivals had been helped to be repatriated back to the continent or to emigrate; ibid., Annual Report, 52 (1910), p. 24.

72. In 1922, there were only twenty-one families whom the Board helped to emigrate and there were no repatriations mentioned in the annual report; ibid., I/I2/9, JBG, Annual Report, 64 (1922), p. 5 I.

73. P.P. (Commons), Session 1909, LXX, "Expulsion of Aliens: Correspondence between the Secretary of State for the Home Department and His Honour Judge Rentoul, KC, on the Subject of the Expulsion of Aliens", pp. $527 \mathrm{ff}$.

74. The number of "criminal aliens" being deported between I905 and I910 amounted to I,793; according to the official report, England and Wales furnished I,7 I I of these, Scotland 72 and Ireland I0. Of the I,7 I I English cases, I,276 occurred in the Metropolis; P.P. (Commons), Session I9I I, X, Aliens Act, I905; Part I: "A Statement with Regard to the Expulsion of Aliens (for the Year 1910), London, I9II”, p. 3. 
immigrants who received poor relief or who were vagrants could also be expelled. ${ }^{75}$ In such cases, the court (often a Justice of the Peace or a magistrate) recommended for deportation aliens who had been in receipt of parochial relief under the Poor Law, who had been "found wandering without ostensible means of subsistence", or who were living under "insanitary conditions" ${ }^{76}$ However, all of these instances only applied to aliens who had entered the country less than a year ago. Nevertheless, deportations under the Aliens Act not only served as sentences on "convicted" immigrants, but could also be employed to remove nonconvicted aliens. However, in the vast majority of cases, aliens were expelled as "convicted" or "criminal aliens". ${ }^{77}$

In contrast to this, the practice of expelling aliens after I9I 8 primarily functioned as a means to regulate immigration and to sanction "irregularities". During the early postwar years, every immigrant who did not comply with the provisions on landing or registration risked being fined, deported, or imprisoned. This concerned new arrivals as well as long-term residents. The case of Abraham Nyman is a characteristic example. In 1923, Abraham Nyman, a sixty-eight year-old Russian Pole who had been living in Britain for forty-five years, was recommended for deportation because he had not registered with the police. He was, as the Jewish Board of Guardians reported, imprisoned for two months for this offence, but had to spend another four months in Brixton prison awaiting his deportation..$^{7}$ As the example of Abraham Nyman shows, aliens who failed to register properly were sanctioned severely. If they did not notify the authorities of their details or did not hold an identity card, they could be fined heavily or were interned. ${ }^{79}$ Particularly during the early postwar years, they also faced eviction. Only those who had valid papers and who could document that they had been monitored by state officials at the border could claim to move "regularly" within Britain. The example of Abraham Nyman also demonstrates that alien subjects were often detained in prison for long periods of time whilst awaiting their deportation. During the early postwar years, the Jewish Board of Deputies dealt with several such cases and complained about

75. Ibid., p. 6.

76. H.S.Q. Henriques, The Law of Aliens and Naturalization (London, 1906), pp. I59-163.

77. Only 47 of the $4 \mathrm{I} 4$ expulsion orders in I910 concerned poor relief cases; P.P. (Commons), Session I9I I, X, Aliens Act, I905; Part I: "A Statement with Regard to the Expulsion of Aliens (for the year 1910), London I9II", p. 6.

78. LMA, BDBJ, ACC/3121/C/02/001/003, Minutes, io April 1923.

79. Out of 108 holders of registration certificates issued by the Metropolitan Police, 2I had been sentenced by a Police Court for failing to report a change to the registered information; $\mathrm{NA}, \mathrm{MEPO}_{35 / \mathrm{I}}, \mathrm{MEPO}_{35 / 2}, \mathrm{MEPO}_{35 / 3}, \mathrm{MEPO}_{35 / 4}, \mathrm{MEPO}_{35 / 13}, \mathrm{MEPO}_{35} / \mathrm{I}_{4}, \mathrm{MEPO}_{35 /}$ I5, $\mathrm{MEPO}_{35} / \mathrm{i} 6$. 

the long periods during which aliens were interned without being
sentenced.

In the interwar period, British authorities began to use evictions in order to sanction any non-compliance (like clandestine entry, or unauthorized stay or employment) with the official regulations concerning immigration. ${ }^{8 \mathrm{I}}$ They increasingly labelled such violations as "irregular" or, though seldom, as "illegal", and criminalized clandestine border crossings and the unauthorized return of aliens by punishing them with imprisonment or deportation. In this context, the changing grounds of eviction mirror the strictness and the growing concern with irregularity that characterized British postwar policy. As mentioned above, before I9I4 the majority of deportees were ordered to leave the country after they had been convicted of a criminal offence (like fraud, larceny, burglary, or forgery). In contrast, the majority of alien deportees in the early i 920 s were deported for landing irregularly, for not possessing a valid passport or not being registered properly - in short, for not having been examined by a state official or not possessing valid identity papers. The evictions thus came to be integrated into an elaborate system of registering and monitoring immigrants. Out of 434 deportation orders that the Home Office registered in an internal list in I 92 I, 23 I ( 53 per cent) were made for a violation of the landing, passport, and registration regulations. ${ }^{82}$ Whereas before the war none of these offences caused an eviction order to be made, they triggered more than half of the postwar orders. ${ }^{83}$

Even though the overall number of evictions from Britain was rather low when compared with Germany ${ }^{84}$ the British migration regime of the early postwar period was strict nonetheless. That non-British citizens could be fined, imprisoned, or deported if they failed to adhere to residency and registration laws shows how the British state used its "monopoly over the legitimate means of movement" to regulate not only

80. LMA, BDBJ, ACC/3I2I/C/02/00I/003, Minutes, 2I July I920; 7 November I92I; 21 March 1922; 10 April 1923. See also the cases that were brought before the Secretary of State in $\mathrm{NA}, \mathrm{HO}_{45} / 24765 / 5$.

8 I. What exactly comprises an "irregular" or "illegal" status - apart from the fact that the term implies a non-compliance with the regulations concerning immigrants - depends on the legislation of the respective state. On the increasing preoccupation of states with "illegal" aliens, see Frank Caestecker, Alien Policy in Belgium, I840-1940: The Creation of Guest Workers, Refugees and Illegal Aliens (New York [etc.], 2000).

82. NA, HO 372/8, List of Deportees.

83. None of these offences occur in the recommendations for expulsion that the Central Criminal Court made under the Aliens Act of 1905; NA, Crim 8/7.

84. According to a declaration in Parliament in 1923 , out of 555 aliens recommended for deportation in 1919, 362 were deported. In 1922, 348 were recommended and 269 deported. These figures do not include the deportations that were ordered independent of a court recommendation; Parl. Debates (Commons), I65 (1923), 21 June 1923, col. I625. 
access to, but also movement within its territory. ${ }^{85}$ Surely, the sudden concern with aliens who landed irregularly or who were not registered reflects a changing political agenda. It reflects a growing determination to exclude "undesirable aliens" and to restrict immigration. Moreover, the new focus on "irregularities" points to the increased administrative powers of the state. By I 9 I 8 the British government possessed elaborate means to monitor alien subjects not only at the borders, but also within the country. By requiring aliens to register and to hold valid documents, officials were maintaining an infrastructure which allowed them a tight (though surely not all-encompassing) control of the immigrants' so-called "regular" or "irregular" status. In this context, the eviction of immigrants came to be employed as a means of enforcing the state's claim to regulate immigration.

That the war allowed governments to gain extended powers and to intervene more decisively in various political fields was surely not a unique development. But when analysing British policy in a comparative perspective, it becomes clear that the trajectories of state intervention in the field of immigration control differed. The outbreak of World War I did not necessarily trigger similar changes in all countries. It did not, at least, in the case of Prussia.

\section{COMPARING BRITISH AND PRUSSIAN POLICIES}

In the German Reich, the diverse German Länder possessed extensive powers regarding the admittance or deportation of foreigners. Prussia in particular, as the largest German state, was foremost in regulating the mobility of foreign migrants from the late nineteenth century onwards. Before World War I, the German Reich attracted hundreds of thousands of labour migrants annually. In view of the high demand for labour in Germany's economy at that time, migrant workers felt encouraged to enter the country and take up work, and their number increased steadily from the I 890 os onwards. In I9I4, about I.2 million foreign migrants were working in the German states, namely in Prussia. ${ }^{86}$ Yet, notwithstanding the need for labour, Prussia's officials strove to prevent certain migrants from residing permanently in the country - especially in its eastern provinces - and employed a complex infrastructure of control for that purpose. Their restrictive political stance has to be placed in the context of an ethnically exclusive nationalist policy, which aimed to exclude foreign Polish and Jewish migrants in particular.

Responding to the need for labour in German agriculture and industry on the one hand, and hoping to prevent incoming Polish workers from

85. Torpey, The Invention of the Passport, p. 3 .

86. Klaus J. Bade, Europa in Bewegung: Migration vom späten I8. Jahrhundert bis zur Gegenwart (Munich, 2000), p. 222. 
settling on the other, Prussian executives installed a complex system of regulations after $1890 .{ }^{87}$ Because of their anti-Polish concerns, they allowed Polish workers to enter the country annually, but requested them to leave every winter. Consequentially, nine out of ten foreign Polish workers left the country every autumn in order to return the following year. From 1908, foreign workers were also forced to acquire work permits in order to be employed regularly and were not permitted to change the workplace allotted to them. There were regular place-of-work inspections, as the Prussian authorities were particularly concerned with "unauthorized" or "irregular" migrants and non-compliance with official regulations. Polish migrant labourers especially, who broke their contract or who did not possess a valid work permit, risked their immediate deportation.

To deport foreigners regularly who were deemed to be "undesirable" was a central instrument employed by the Prussian government in order to regulate immigration. Foreigners did not have any legal right of residence in the German states. ${ }^{88}$ They could be compelled to leave at any time and without any reason given, as the following petition illustrates: “The police call us 'annoying aliens', but why we are annoying, we don't know. [...] We are paying taxes and without any reason we are all persecuted by the police and evicted." ${ }^{89}$ Addressing their letter to the Prussian Ministry of the Interior, three brothers who had emigrated to Berlin from Poland and were about to be deported in April 1922, expressed their lack of understanding concerning the rationale of Prussian policy. Their fate of being forced to leave the country was shared by many other migrants at the time. Letters like the one of Samuel, Simon, and Burech Gross cited above can be found in numerous Prussian files from the I 880 s onwards. They reflect the insecure status of immigrants in the Prussian migration regime - both before and after the war.

Throughout the late nineteenth and early twentieth centuries, the Prussian authorities repeatedly ordered the deportation of foreign citizens - not for any individual reason, but as a consequence of their ethnicity.

87. Idem, Land oder Arbeit? Transnationale und interne Migration im deutschen Nordosten vor dem Ersten Weltkrieg (Osnabrück, 2005, http://www.imis.uni-osnabrueck.de/BadeHabil.pdf); idem, 'Preußengänger' und 'Abwehrpolitik'. Ausländerbeschäftigung, Ausländerpolitik und Ausländerkontrolle auf dem Arbeitsmarkt in Preußen vor dem Ersten Weltkrieg", Archiv für Sozialgeschichte, I4 (1984), pp. 9I-I62; idem, "Politik und Ökonomie der Ausländerbeschäftigung im preußischen Osten I885-I9I4. Die Internationalisierung des Arbeitsmarktes im 'Rahmen der preußischen Abwehrpolitik”, in Hans-Jürgen Puhle et al. (eds), Preußen im Rückblick (Göttingen I980), pp. 273-299.

88. Ernst Isay, Das deutsche Fremdenrecht (Bonn, I923), p. i I 5 .

89. Geheimes Preußisches Staatsarchiv, Berlin [hereafter, GStA], HA I, Rep. 77, tit. I I76, Nr. IG, vol. 7, Bl. I s, "Letter by Samuel, Simon and Burech Gross to the Prussian Minister of the Interior”, I3 March 1922. 
Anti-Polish and anti-Semitic attitudes motivated the mass expulsions in the mid-I880s, as a result of which about 32,000 foreign Poles and Jews were forced to leave Prussia. ${ }^{90}$ And during the following four decades, the Prussian authorities repeatedly ordered foreign citizens to be deported as a consequence of their ethnicity, religion, or social status. These evictions followed the ethnically exclusive agenda of Prussia's overall policy. As in Britain, deportations were also used in order to penalize any non-compliance (like clandestine entry, unauthorized stay, or illegal employment) with official regulations concerning migration. And although a deportation order could be made on various grounds, ${ }^{9 \mathrm{I}}$ irregular entry to the country was, as in Britain, a major reason for orders to be made. Expulsion figures from the I 920 s illustrate this. In 1926, for example, the Prussian authorities made deportation orders in 3,305 cases. About 23 per cent were made against migrants who had entered the country irregularly, who did not possess a valid ID card or who had not registered with the police..$^{2}$ But, while in Britain, the concern with "irregular migrants" only became noticeable after 19I8, the Prussian authorities had begun to punish their unauthorized stay well before the war.

The authorities in Prussia deemed that deportations were generally acceptable in the interest of "public safety, peace and order". In contrast with Britain, it was not the Minister or a ministerial official who made the deportation orders. They could be ordered by regional state officials, who possessed far-reaching powers in that respect. ${ }^{93}$ Moreover, the evictions did not follow any juridical decision. This was partly because the transport of deportees did not entail the payment of expensive passages, as it did in Britain. The practice of expelling unwanted migrants was used extensively in the German states, whereas Britain, being an island, relied more on its border controls. In Prussia deporting unwelcome foreigners was considered a flexible and convenient form of controlling immigration from the i 880 s. And by the early i920s, this policy had not changed much. However, in I 92 I the Prussian Minister of the Interior decreed that long-term residents were to be exempted from deportation. ${ }^{94}$ Also, more definite guidelines as to the actual grounds of eviction were formulated, and both changes benefited the immigrants staying in the country. They

90. Neubach, Die Ausweisungen von Polen und Juden.

91. See the decree of 24 August 1923, in Max Hahn, Die amtlichen Bestimmungen über die Ausweisung lästiger Ausländer (Berlin, 1927), pp. 5-I I.

92. Bundesarchiv Berlin-Lichterfelde, R/901/25657.

93. In Prussia, the Regierungspräsidenten had the power to make deportation orders; Isay, Das deutsche Fremdenrecht, pp. 199-247; Hahn, Die amtlichen Bestimmungen.

94. Ministerialblatt für die Preußische Innere Verwaltung (I92 I), Nr. 36I, I 8 October I 92 I, pp. 372-376. See also the later decree of 24 August 1923, in Hahn, Die amtlichen Bestimmungen, pp. 5-II. 
hardly diminished the prevalence of the practice though. The numbers of deportees, before and after the war, remained equally high. ${ }^{95}$ So if it came to the practice of evicting foreign immigrants, the war did not lead to major changes in the Prussian policy. The deportation policy does not indicate a restrictionist turn after I9I4. Rather, it indicates a continuously strict immigration policy.

Certainly, the forced removal of foreign migrants was just one, though an important, element of the Prussian migration regime, and the fact that it was used in a similar way before and after the war might seem negligible. After I9I8, Germany encountered a high influx of refugees fleeing the political situation in eastern and central Europe. ${ }^{96}$ In an atmosphere already charged with anti-Semitism, the increased number of, mostly Jewish, migrants from the east was perceived as a major threat. ${ }^{97}$ Responding to the widespread demand for a restrictive political stance, German authorities began to implement tight passport and visa regulations. In addition to enforced entrance controls, Prussia, as well as other German Länder, also established stricter regulations regarding registration with the police. ${ }^{98}$ The new measures were mainly introduced in order to achieve a tighter control of eastern European Jews in the immediate postwar period. They were closely linked to a policy of internment and expulsion. ${ }^{99}$ Foreign citizens who were unable to prove that they had sufficient accommodation and "useful" employment, or who had been convicted of a crime, faced deportation or internment.

95. While from January until the beginning of October I9I4 foreign immigrants had been ordered to be expelled from Prussia in 2,220 cases (657 thereof until April I914), I,640 orders were made between January and the end of October 192 I. Numbers are according to ZentralSteckbriefregister, I I (I914); Zentral-Steckbriefregister, I 8 (I92 I).

96. It was estimated at the time that by I92 I about 70,000 eastern Jewish refugees had come to Germany; Salomon Adler-Rudel, Ostjuden in Deutschland, I880-1940. Zugleich eine Geschichte der Organisationen, die sie betreuten (Tübingen, 1959), pp. I I9f.; Trude Maurer, Ostjuden in Deutschland 1918-1933 (Tübingen, 1985); pp. 65f. Also, about 100,000 Russian refugees were staying there in 1919, and their number amounted to 600,000 by 1922/1923 (which, according to Oltmer, was probably too high an estimate); Jochen Oltmer, Migration und Politik in der Weimarer Republik (Göttingen, 2005), pp. $262 \mathrm{f}$.

97. Steven E. Aschheim, Brothers and Strangers: The East European Jew in German and German Jewish Consciousness, I800-1923 (London, 1982), pp. 230-245; Maurer, Ostjuden in Deutschland, pp. 104-160; Ludger Heid, Maloche - nicht Mildtätigkeit. Ostjüdische Arbeiter in Deutschland I914-1923 (Hildesheim [etc.], I995), p. 60.

98. Christiane Reinecke, "Documented Movements: Registration Policies and Migration Control in Britain and Germany after the First World War", in Jochen Oltmer et al. (eds), Refugees, Innovators, or Enemies? Migrants from Eastern Europe in Weimar Germany (Oxford [etc.], 2009).

99. On the internment in so-called concentration-camps see ibid. and Ludger Heid, "Die Juden sollen ruhig verbrennen'. Ostjuden im Konzentrationslager Stargard (I92I)", in Margret Heitmann et al. (eds.), 'Halte fern dem ganzen Lande jedes Verderben'. Geschichte und Kultur der Juden in Pommern (Hildesheim [etc.], 1995), pp. 40I-428. Maurer, Ostjuden in Deutschland, pp. 416-435. 
Moreover, in reaction to high unemployment, the German authorities introduced annual quotas in order to limit the number of foreign migrants in the German postwar economy. The regulations on labour migration did not concentrate mainly on foreign Polish seasonal workers any more, as they had before I9I4, but expanded and came to concern all migrant labourers. ${ }^{100}$ After 1918, powers to regulate the employment of immigrant workers became increasingly centralized and were more clearly defined as a domain of the German state. ${ }^{\text {IOI }}$ The policies of the diverse German Länder became more concerted and Reich ministries like the Ministry of Labour gained influence. The German state aimed to regulate access to the labour market in order to give precedence to German citizens, parallel to the (less efficient) British attempts to limit the admission of incoming migrant workers in the interests of British workers. Because of a high unemployment rate and an increasingly nationalized labour market, migrant workers now faced tighter restrictions regarding their entry and employment. ${ }^{102}$ Serving as a disposable workforce, their access to the country and its labour market was clearly more limited than before I9I4. ${ }^{\text {I03 }}$ But while the aims regarding labour-market policy expanded, for the most part the logistics employed in order to implement them already existed. At least the Prussian authorities could make use of existing institutions (like the "Deutsche Arbeiterzentrale" for the handing out of work permits) and well-tried processes (like the work-permit system itself).

Like the continuities in Prussia's deportation policy, this serves to illustrate that the German authorities after 191 8 fell back upon bureaucratic tools that had been used well before i9i4. Whether it be border controls, registration with the police, regular statistical reports, work permits, workplace inspections, or the forced annual removal and expulsion of migrants - the whole kit that made immigration control possible was already in place in pre-war Prussia. Hence, World War I did engender important changes in Prusso-German migration policy. But in order to implement their political aims the authorities made use of an infrastructure that had been established earlier on.

By 1920, the British and the German migration regimes had come to resemble each other. Complying with the establishment of an international

I00. There were some specific regulations for Polish workers though. The pre-war practice of forcing Polish workers to leave at the end of each year for example was reintroduced by the mid-1920s, after having been suspended in the early I 920 .

I0I. Jochen Oltmer, "Einleitung. Steuerung und Verwaltung von Migration in Deutschland", in idem, Migration steuern, pp. 9-56, I9-24.

I02. Idem, "Schutz des nationalen Arbeitsmarkts': transnationale Arbeitswanderungen und protektionistische Zuwanderungspolitik in der Weimarer Republik", in idem, Migration steuern, pp. 85-1 22; idem, Migration und Politik.

I03. At the same time, migrants who had been resident in the country for several years could be exempted from the restrictions and gained unhindered access to the labour market. 
passport regime, foreign citizens travelling to either Britain or Germany after World War I had to produce a passport and - at least during the early postwar years - a visa. ${ }^{104}$ In both countries, they needed a work permit in order to get access to the labour market, as native workers were given priority over foreign ones. And in Britain, as well as in Germany, immigrants were required to register with the police, facing eviction if they did not. As they shared the bureaucratic ideal of control, the British and German authorities were equally concerned with "irregular" immigrants. ${ }^{105}$ But unlike in Britain, most of the administrative instruments employed were already in use in pre-war Prussia. So when it comes to the state's infrastructural powers and the administrative practices employed, I9I4 in Prussia was a less perceptible caesura than in Britain. The early I920s, however, can be seen as a terminus ante quem for the establishment of restrictive migration regimes. By then, both states had equally elaborate bureaucratic tools at their disposal in order to monitor and control immigration.

\section{CONCLUSION}

Generally speaking, the key principles of a "high modernism", as James C. Scott has defined it, ${ }^{106}$ namely "standardization, central control, and synoptic legibility to the centre" came to characterize the British immigration policy of the war and postwar period. Striving for systematic surveillance, the standardized forms of classifying, registering, and documenting the movement of immigrants became crucial elements in the British migration regime. Thereby, the logic of a security policy that considered aliens as a political and military risk was a major factor in the restrictions being prepared internally before the war, and becoming law in I9I4. This factor combined with a number of other long-term developments. In the tradition of Poor Law provisions, the British authorities aimed to reduce the number of public charges. They strove to deport criminal aliens in the name of "public safety", and they aimed to exclude insanitary immigrants in the name of "public health". These concerns responded to the xenophobic, and at times anti-Semitic, quest to reduce

104. Salter, Rights of Passage, pp. 77-100; John Torpey, "Passports and the Development of Immigration Controls in the North Atlantic World during the Long Nineteenth Century", in Fahrmeir, Migration Control, pp. 73-91.

I05. Caestecker speaks of the "creation" of the "illegal" or "undocumented" alien in Belgian immigration politics; Caestecker, Alien Policy in Belgium, pp. 279-287. On the study of irregular migration in general see G. Sciortino, "Between Phantoms and Necessary Evils: Some Critical Points in the Study of Irregular Migrations to Western Europe”, IMIS-Beiträge, 24 (2004), pp. 17-45.

106. Scott, Seeing Like a State, pp. 87-I46, 219. (In this particular section, Scott refers to the Soviet state. Nevertheless, he refers to these "modern principles" throughout his book.) 
the number of immigrants. Moreover, the racialized concern to prohibit "coloured" subjects from becoming resident influenced postwar alien policy. While the passing of the Aliens Act in 1905 had already initiated the establishment of immigration controls, the beginning of World War I saw a considerable extension of executive powers in the name of "national security". With the executive aiming for extended powers on the one hand, and a highly nationalized public demanding the exclusion of aliens on the other, the war functioned as a catalyst to existing restrictive tendencies.

In order to situate the British and Prussian examples in the historical debates on an emerging "international restrictive migration regime", three aspects seem to be particularly relevant.

(I) In order to understand the implications of immigration control before, during, or after the Great War, the actual administrative practice has to be taken into account. The micro-mechanical perspective on the way in which immigration was managed draws attention to the various actors in charge and points to the changing relationship between the state and the migrant. It suggests a chronology of control that does not always correspond with overall political changes. As, for example, the British and Prussian practice of evicting aliens shows, I9I4 marked a significant turning point in the actual policing of immigrants in Britain, while there was no remarkable shift in the Prussian politics of expulsion.

(2) Changes in immigration policy did not only derive from increasingly restrictive political objectives, but also depended on an expanding infrastructure that facilitated a more efficient implementation of political aims. Hence, the growing interventionism in the field of immigration should be related to the simultaneous expansion of the modern state apparatus in the late nineteenth and early twentieth centuries. In that period, the nation state's capacity to intervene in various fields of social life (like the labour market, social welfare, etc.) grew. The emergence of a modern bureaucratic infrastructure and the overall increase in infrastructural powers contributed to a tighter implementation of immigration controls.

(3) In this context, a growing concern with irregular migration indicated that the regulative endeavours had reached an advanced state, as the authorities became concerned with the efficiency of their own controls and began to penalize those who did not comply with the regulations. While in Prussia that point had already been reached in the years preceding the Great War, Britain reached it by I9I 8 . 